This item was submitted to Loughborough's Research Repository by the author.

Items in Figshare are protected by copyright, with all rights reserved, unless otherwise indicated.

\title{
Organisational design for improved performance of urban water utilities in developing countries
}

PLEASE CITE THE PUBLISHED VERSION

https://doi.org/10.1016/j.jup.2017.10.001

PUBLISHER

(C) Elsevier

VERSION

AM (Accepted Manuscript)

\section{PUBLISHER STATEMENT}

This work is made available according to the conditions of the Creative Commons Attribution-NonCommercialNoDerivatives 4.0 International (CC BY-NC-ND 4.0) licence. Full details of this licence are available at: https://creativecommons.org/licenses/by-nc-nd/4.0/

\section{LICENCE}

CC BY-NC-ND 4.0

\section{REPOSITORY RECORD}

Kayaga, Sam, William Kingdom, and A. Jalakam. 2019. "Organisational Design for Improved Performance of Urban Water Utilities in Developing Countries”. figshare. https://hdl.handle.net/2134/27129. 


\title{
Organisational design for improved performance of urban water utilities in developing countries
}

\author{
S.M. Kayaga ${ }^{\dagger}{ }^{\dagger}$, W. Kingdom** and A. Jalakam*** \\ * Water, Engineering and Development Centre (WEDC), School of Architecture, Building and Civil Engineering, \\ Loughborough University, Leicestershire LE11 3TU, UK. \\ ** Water Global Practice, The World Bank, 1818 H Street NW, Washington, DC 20433, USA. \\ ***Jalakam Solutions Private Limited, 234, 10th C Main, 1st Block, Jayanagar, Bangalore, 560001, India.
}

\begin{abstract}
Unclear roles and responsibilities and other factors related to organisational design, have been found to be some of the common barriers to providing good urban water services in developing countries. A comparative study commissioned by the World Bank in 2013 assessed how five well-performing water utilities located in different parts of the world aligned their organisational structures and management systems with their strategies and the operating environment. Lessons therefrom can be adapted for organisational (re)design of water utilities, for their improved performance, subject to enabling factors in the individual organisation's operating environment.
\end{abstract}

Key Words: organisational design, organisational performance; water utilities

\section{Introduction and background}

Most urban water service providers in developing countries, many of which are publicly owned water utilities do not provide adequate levels and quality of water services, a situation that severely constrains sustained growth and poverty alleviation in the urban areas (Misra and Kindgom, 2012). A publicly owned utility may be defined as an organization that is majority-owned and controlled by government, and (i) a government ministry/department; (ii) a statutory body; or a government-owned private company. Common barriers to providing good levels of service are unclear roles and responsibilities, limited autonomy and accountability, low levels of cost recovery, lack of a commercial and customer orientation, and weak professional capacity (Baietti et al., 2006).

In 2015, more than 660 million people in the world were using unimproved water supply sources, about half of which lived in sub-Saharan Africa. Although access to improved drinking water sources is higher in urban areas of least developed countries (86\% population coverage, compared to $62 \%$ in rural areas in 2015), only $32 \%$ of the urban residents have access to piped water supply to their premises, with $30 \%$ using other improved water sources such as public taps or standpipes, tube wells or boreholes, protected dug wells, protected springs, and rainwater collection, and the rest (38\%) using unimproved water sources (UNICEF and WHO, 2015; 2017).

A study of eleven urban water utilities worldwide carried out by the World Bank in 2005 identified the following key attributes of well-performing public water utilities (Baietti et al., 2006):

- Autonomy. The degree of independence from external interference, exercised by water utility managers in making important decisions;

\footnotetext{
${ }^{\dagger}$ Corresponding author - email s.m.kayaga@Lboro.ac.uk
} 
- External accountability. The water utility's obligation to account for performance results to the government, the owners;

- Internal accountability. The utility's management and staff need to be held accountable for achieving organisational performance targets;

- Customer orientation. A business philosophy that enables a utility to listen to their customers and work to better meet their needs;

- Market orientation. A management philosophy that introduces market-style incentives and promotes greater use of markets for the delivery of water services; and

- Corporate culture. A combination of corporate values, vision, mission, as well as moral, social, and behavioural norms that inspire staff and managers to excel.

All these attributes are related to Organisational Design (OD). OD has been described as the process of developing a strategy, i.e., objective, scope, competitive advantage, and logic; and mapping it onto an organisation, i.e., people, architecture, routines, and culture; so as to maximise performance in a given operating environment (Roberts, 2007). In a groundbreaking study published in 1992, Kaplan and Norton developed the Balanced Scorecard, initially for performance measurement, which was later transformed into a tool for strategic management. The Balanced Scorecard is based on the premise that financial performance lags other dimensions of organisational performance. In other words, exclusive reliance on financial indicators could create a situation in which long-term value creation is sacrificed for short-term performance (Kaplan and Norton, 2001a). The Balanced Scorecard can be utilised to align key management processes and systems to the organisational strategy (Kaplan and Norton, 2001b, Kaplan, 2010), i.e., the process of OD.

Although a lot of documented literature exists on OD for organisations in the private sector, there is scanty information on OD for public sector organisations such as public water utilities. This paper examines the process of adapting OD principles to urban water utilities. From the onset, it is important to note that OD is not a panacea for sustained organisational performance. OD must be well aligned with other aspects institutional capacity, i.e., key technical and functional capacities, including the organisation's ability to influence its external environment in a positive and strategic manner (UNDP, 2008).

This paper is based on a study commissioned by the World Bank in 2013-14 to carry out rapid assessment to identify typical organisational structures, staffing levels and management systems for well-managed water utilities throughout the world. These findings would be used to inform the design of organisational structures and operating systems for urban water utilities. Increasingly, water utilities in various regions of the world are using benchmarking as part of a system to promote organisational and performance improvement.

Benchmarking can inform decision-makers about the performance of water utilities and help identify areas for improvement. However, benchmarking is not without shortcomings. Organisational performance, similar to institutional capacity, is greatly influenced by factors in the external environment in which an organisation operates (Baser et al., 2008).

Furthermore, care must be taken to ensure that those being assessed do not 'game' the system (Berg, 2010). Finally, benchmarking can lead to isomorphic mimicry of presumed good practices on the part of the participating water utilities (Andrews, Pritchett, and Woolcock; 2012).

In this paper, we limit our coverage to the findings from the comparative study of five water utilities in Africa, Europe and South East Asia regarded as "effective" in terms OD. We exclude from our assessment the actual process of benchmarking or project status. The paper 
is structured as follows: the next section presents the methods used in the comparative study; Section 3 provides a brief discussion of the key concepts related to OD; Section 4 reports the results; and Section 5 presents the summary and conclusion.

\section{Methods}

To begin, we carried out a literature review on OD concepts. We confined our comparative study to urban water utilities that provide services to populations between 500,000 and 2 million. We then reviewed the World Bank's International Benchmarking Network for Water and Sanitation Utilities (IBNET) 2010 database, and identified seven well-performing water utilities from developed and developing countries, with which we have previously had established contacts, for ease of obtaining the necessary information and data. Evaluation of performance was based on IBNET Apgar scores concerning: (i) water supply coverage, (ii) sewerage coverage (where applicable), (iii) level of non-revenue water, (iv) collection period, (vi) operating cost coverage ratio, and (vi) affordability of water and wastewater services (The World Bank, 2014) We contacted suitable key informants from the identified water utilities in developing countries and developed countries, which had a 2010 Apgar score of at least 7 and 10, respectively. Two water utilities from developing countries and four from developed countries agreed to participate in the study.

We designed a standard data collection form and pre-tested it with one participating company in mid-2013 but using a different key informant. The questionnaire had sections on strategic orientation and scope of service delivery; organisational structure/staffing; key organisational resources; the planning process; human resources management/development; technical process management; commercial process management; financial and asset management; and performance management. In the autumn of 2013, an improved version of the questionnaire was sent to the water utilities that had agreed to participate. Research design and data collection methods conformed to the International Federation of Social Workers' (IFSW) Ethics in Social Work, Statement of Principles (2004) [refer to http://ethics.iit.edu/ecodes/node/3934, accessed on $14^{\text {th }}$ July 2013]. Where necessary, emails, phone calls, or personal visits were used to clarify issues and fill any data gaps. We received duly filled questionnaires from five out of six targeted organisations. Data were analysed and reported using matrices and graphs.

\section{Organisational Design Concepts}

What is an organisation?

There are small variations in the way organisations are defined in the literature, but all of the definitions have one commonality: that an organisation is purposeful. Most scholars (e.g. North, 1990; Huczynski and Buchanan, 2007; Katz, 1966) define an organisation as a group of individuals bound by some common purpose to achieve set objectives. However, an organisation, '....in its simplest form .... is a person or group of people intentionally organized to accomplish an overall, common goal or set of goals' (McNamara, 2015). McNamara's definition recognises that the critical factor of an organisation is the existence of intentionally established goals, regardless of the number of people making up the organisation.

Some authors add the aspect of 'control' to the definition of an organisation. For instance, Huczynski and Buchanan (2007, p.6) define an organisation as a '...social arrangement for achieving controlled performance in pursuit of collective goals'. Hence, organisations consist of a group of individuals working together to achieve a specified goal(s), with the engagement being coordinated in a controlled manner. This definition also implies that individuals 
working on their own do not constitute an organisation - there is need to have a structure, which will enable individuals to work together towards a common goal. Furthermore, the element of controlled performance points to the need to have systems and procedures to ensure that the common goals are achieved. Another important aspect of an organisation is that it does not exist in a vacuum, but engages with an external environment - it should interact with customers, suppliers, competitors, and other elements of the external environment (Conner et al., 2012; Daft, 2007). All these aspects that are captured in the definition of an organisation point to the need for OD (Conner et al., 2012).

\section{What is Organisational Design (OD)?}

Traditionally, OD was narrowly defined as the process of creating an organisational chart. In the contemporary times, OD is conceptualised as being much wider - an organisational chart is only one of the manifestations of the organisational design process (McGee and Molloy, 2003). According to Daft and Lewin (1993), organisational design is concerned with the organisation's formal architecture, culture, strategy and employment relations. OD has been defined as the practice of consciously aligning an organisation's structure, processes, management systems and culture with a well-articulated strategy (McGee and Molloy, 2003). Through OD, managers can achieve coordinated effort in the organisation, by predetermining the structure of the task and authority relationships: the purposive and goal-oriented structure is consistent with the definition of an organisation which pursues collective goals, in a wellcoordinated and controlled manner (Huczynski and Buchanan, 2007).

The starting point of OD is the strategy. An organisational strategy may be defined as the articulation of the organisation's vision, mission and core competences. A mission statement is a description of why the water utility exists, and a vision statement is where the organisation wants to be, and how it wants to be seen by the external publics. Organisations usually also clarify what their core values are. The core values of an organization are those values which form the foundation on which the staff perform work and conduct themselves (Connor et al., 2012; Roberts, 2007). OD, a role for the top management team, is crucial for successfully executing the organisational strategy.

An important factor to be considered in developing the strategy and in the whole OD process is the external environment in which the organisation operates. Senior managers need to periodically scan the environment, using tools such as the PESTLE (political-economicsocial-technological-legal-environment) analysis; as well as carry out a stakeholder analysis to identify the various stakeholders, their needs, and how to continuously meet them. The third important factor is the organisation culture, based on shared assumptions, attitudes, beliefs, values, customs, as well as written and unwritten rules - these develop in an organisation over time, are considered valid, and govern how people behave in organizations (Connor et al, 2012; Sepehri et al, 2011; Roberts, 2007).

The core function of OD is the process of designing and creating an organisation that will deliver the strategy. According to McGee and Molloy (2003) OD:

- provides greater ability for appropriately allocating human and financial resources to specific areas to drive the corporate strategy;

- ensures that the right information is transmitted to the right staff at the right time;

- enables the development of a high-performance culture; and 
- enables senior management to reallocate resources and adapt to market forces as and when necessary.

Roberts (2007) coined the acronym 'PARC' to represent key features of an organisation that should be considered in the process of creating an organisation. These include people and other organisational features, namely architecture, routines, and culture. Senior Managers must identify what skills, competences, beliefs and tastes the people in the organisation should have in order to deliver the strategy. The key architecture features concern the relatively hard organisational features, which are discussed in greater detail in the following sub-section. There are soft features of architecture that are equally important, namely the personal networks that link the people within the organisation internally and externally. Routines are the policies, managerial processes, and procedures (formal and informal, official and unofficial) that inform how (i) management decisions are made; (ii) resources are allocated; (iii) data and information are gathered and transmitted; (iv) performance is monitored; and (v) activities are recorded and rewarded. Lastly, culture is a soft organisational feature that captures (i) the shared values and beliefs of the people in the organisation; (ii) the common language used in the organisation that shapes thoughts and actions; (iii) the fundamental mind-set and mental model which shapes how members of the organisation deal with each other as well as outsiders; and (iv) the context in which the relationships in the organisation are developed, and the basis for implicit contracts that guide and shape organisational decisions (Roberts, 2007).

Other scholars (e.g. Conner et al., 2012; Sepehri et al., 2011; Simons, R., 2005) have highlighted the following aspects that are important features of an organisation:

- The processes (i.e., a set of activities, that use resources to transform inputs into outputs), as well as the systems (i.e., groups of interacting, interrelated, or interdependent processes) deployed in the organisation;

- Measurement of organisational performance, with financial performance being one of the most dominant measures considered by businesses and other organisations. Other key performance measures are customer orientation, internal business processes, and organisational learning and growth (Kaplan, 2010; Kaplan, 2005; Kaplan and Norton, 2001a; 2001b). A useful measure is complete, objective and responsive to the efforts of individual staff members who are being evaluated;

- Technology deployed in the organisation for production and other functions, which affects the structural dimensions of the organisation such as formalisation, centralisation and span of control. For example, empirical research in the US reported in Connor et al. (2012) has found that there is greater demand for information technology in organisations with greater investments in human capital and higher levels of decentralisation of decision-making; and

- The level of conformity to physical requirements, such as ergonomics, health and safety, staff well-being, working environment and space.

Some of these factors have been integrated into overarching models termed as static organisational design models, in which leadership has been projected to be the driving force. An example of such a static organisational design model is McKinsey's 7-S model (Kaplan, 2005). On the contrary, dynamic models consider OD as a transformation process, in which the key input is organisational strategy, with performance as the key output, as shown in Figure 1. 


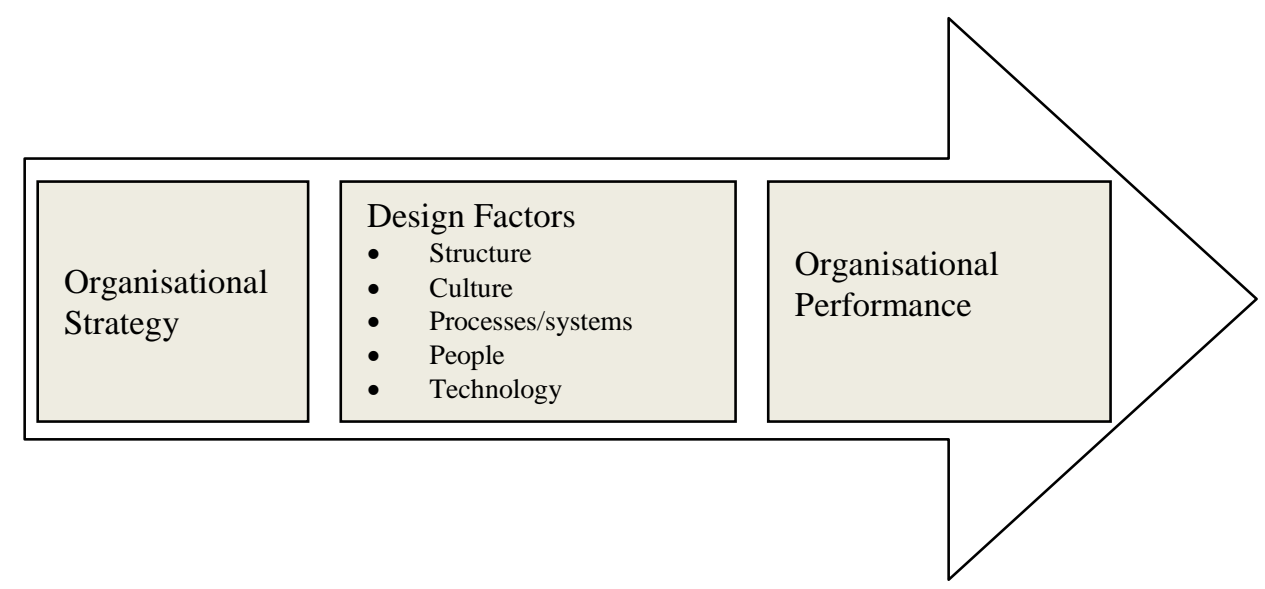

Figure 1: An outline of a dynamic model of organisational design (Source: Connor et al., 2012)

The dynamic model shown in Figure 1 operationalises leadership through strategic direction (Connor et al., 2012). According to Roberts (2007), the level of organisational performance depends on the extent of the fit among three key elements: organisational strategy, organisational features, and the environment in which the organisation operates. Since the operating environment is constantly changing, top managers are expected to continuously scan the external environment, and respond to it by making the necessary changes in the organisation (Bhattacharya and Kundu, 2013; van de Ven, 1976).

\section{Primary Dimensions of Organisational Structures}

The organisational structure is one of the key manifestations of OD and defines the division, grouping and coordination of tasks carried out in the organisation. Structure is displayed in the form of an organisational chart, is agreed upon by senior managers, and should provide clarification on the roles and responsibilities of the various staff members. Six key dimensions should be considered in the design of an organisational structure, and each affects how the tasks are performed in the organisation (Sepehri et al., 2011). These are (i) work specialisation; (ii) departmentalisation; (iii) chain of command; (iv) delegation of authority; (v) span of control; and (vi) formalisation. Unless otherwise stated, most of the concepts highlighted in this and the next sub-section have been adapted from Sepehri et al. (2011) and Connor et al. (2012).

Work specialisation or division of labour concerns how the tasks in the organisation are subdivided into separate jobs, or the extent to which the jobs are specialised. The more a job is created into smaller separate tasks, the more specialisation is required in undertaking the tasks. This specialisation will be in the form of occupational and professional specialities, and/or in terms of tasks grouped in a natural sequence of work, such as a manufacturing plant dividing work into fabricating and assembling functions. Departmentalisation is the manner in which jobs are grouped, and is driven by the need to effectively coordinate the different families of jobs. The jobs can be grouped in various ways, such as job function, product line or geographical location. The most commonly used department bases are briefly described in the next sub-section.

In every organisation, there is a chain of command, which spells out the organisation's hierarchy of reporting relationships. The chain of command provides a line of authority and decision-making power, indicating which staff in the organisation reports to whom. Related to the chain of command is the dimension on delegation of authority or centralisation and 
decentralisation. Delegation of authority is the decision on how much authority is delegated to each job held by various staff. Authority may be defined as the institutionalised power given to an individual jobholder to make decisions and carry out their responsibilities without seeking approval from higher management (BusinessDictionary.com, 2015). Decentralising authority encourages the development of management capabilities of professional staff and creates a competitive climate within the organisation, which may lead to creativity and innovation, but could also be detrimental to an internal collaborative working environment. Decentralised authority requires higher levels of capacity development for the middle managers; leads to duplication of functions; and translates into higher monitoring and evaluation costs.

The organisational structure also informs the appropriate number of staff members reporting to each manager or span of control, which also determines the number of managers in the organisation. Organisations with larger spans of control are more efficient than those with smaller spans of control. However, without an optimum balance staff members will not receive adequate support and leadership. The final important dimension of an organisational structure is formalisation, referring to the extent to which rules, procedures and other operational guidelines are documented and enforced. A highly formalised job will have welldefined and clearly documented procedures, leaving the staff with little freedom of choice in the way they execute the tasks. However, the mere presence of manuals of procedures, rules and policies in an organisation does not necessarily make it highly formalised; these rules and procedures must also be enforced if they are to affect organisational behaviour.

\section{Common Departmental Bases}

The preceding sections show that organisational design entails more than simply creating a diagrammatic structure. However, an organisational structure is the most easily recognised output of OD (Conner et al., 2012). Based on the choices made by senior managers, organisational structures vary along the dimensions described in the preceding section. There are several basic bases that are adopted to create commonly-used structures. Functional organisations have a structure that reflects different functions represented in the organisation. The specific configuration of functional departments depends on the emphasis placed by senior management. For a manufacturing organisation, examples of such functions include production, marketing, sales, research, and human resources management. The main advantage of having functional departments is the enhanced efficiency that emanates from experts working together under one supervisor. A major disadvantage is that such an arrangement may lead to higher levels of compartmentalisation according to areas of specialisation.

When organisations expand their operations to diverse geographical areas, the organisational structure may be designed according to geographical departmentalisation, in which organisational departments are established according to geographical areas within or across national borders. For an urban water utility, the departments may be aligned according to the urban service areas and/or regional zones. The departmental managers are given the responsibilities for managing all of the operations in the geographical areas, which enhance the capacity of managerial staff. The geographically centralised departments are good for large organisations where physical separation of activities makes centralised coordination difficult. Furthermore, geographical departments provide a good basis for making decisions to make the product or service responsive to local needs in the regional market. However, there is need for the head office to offer guidance to managers and to carry out considerable control, to ensure that the geographical branches are working towards a common corporate vision. 
Another basis for structuring an organisation is through product departmentalisation, common among large utilities that group jobs according to product and/or service portfolios. All tasks relate to producing and selling a product or service are placed under the supervision of one manager. Hence, the department develops and retains staff expertise in researching, producing and distributing a product or service. Although some aspects of the functional organisation are ingrained in this type of structure, the dominant base is the product departmentalisation. The product-based organisations have the potential to promote entrepreneurial capacity, but they could also breed rivalry between different departments. Organisations could also be structured to reflect the types of customers/markets they serve, i.e., using customer departmentization as a basis. For instance, a loans division of a commercial bank may be structured according to industrial, commercial, or agricultural loans. The main advantage associated with the customer departmentalisation is its capacity to respond quickly to the changing needs of various customer segments.

Finally, the matrix model of departmentization attempts to combine functional and product / geographical/ customer departmental bases, and '... sets out to reconcile the competing demands of customers and the need for a strong bureaucratic and efficient functional presence' (Conner et al., 2012, p.9). This balance is achieved by superimposing a horizontal structure of authority, communication and influence onto the vertical structure. The matrix design, which is commonly applied in organisations that are highly project-based, creates a dual authority system, whereby staff report to their functional manager as well as to their line manager who may be heading the department in charge of the product, geographical area, customer segment or project. Several advantages are associated with the matrix model: (i) it may facilitate the efficient utilisation of human and material resources; (ii) owing to the fast communication through vertical and horizontal channels, staff are able to make quicker response to changing conditions in the business environment; (iii) it creates an environment in which people of different specialisms interact, and greater organisational learning; and (iv) with the greater interaction, the decision-making process tends to be participative, which in turn leads to higher levels of motivation and commitment amongst staff members.

\section{Findings from the comparative study}

\section{Overview of the benchmarked water utilities}

Responses were received from five water utilities: one from South East Asia, one from Africa, one from mainland Europe and two from the United Kingdom. In conformity with confidentiality requirements, the identities of water utilities have been kept anonymous, and have been labelled as A, B, C, D and E respectively. Table 1 summarises the general characteristics of the responding water utilities. 
Table 1: Overview of the participating water utilities

\begin{tabular}{|c|c|c|c|c|c|}
\hline & A & B & $\mathrm{C}$ & $\mathrm{D}$ & E \\
\hline $\begin{array}{l}\text { Region/ } \\
\text { Country }\end{array}$ & $\begin{array}{l}\text { Central } \\
\text { Europe }\end{array}$ & $\begin{array}{l}\text { South East } \\
\text { Asia }\end{array}$ & $\begin{array}{l}\text { United } \\
\text { Kingdom }\end{array}$ & $\begin{array}{l}\text { Sub-Saharan } \\
\text { Africa }\end{array}$ & $\begin{array}{l}\text { United } \\
\text { Kingdom }\end{array}$ \\
\hline Legal status & $\begin{array}{l}\text { Public } \\
\text { company }\end{array}$ & $\begin{array}{l}\text { Statutory } \\
\text { body }\end{array}$ & $\begin{array}{l}\text { Private } \\
\text { Company }\end{array}$ & Statutory body & $\begin{array}{l}\text { Private } \\
\text { Company }\end{array}$ \\
\hline $\begin{array}{l}\text { Type of } \\
\text { services }\end{array}$ & Water services & $\begin{array}{l}\text { Water } \\
\text { services }\end{array}$ & $\begin{array}{l}\text { Water } \\
\text { services }\end{array}$ & $\begin{array}{l}\text { Water \& } \\
\text { sewerage } \\
\text { services }\end{array}$ & Water services \\
\hline $\begin{array}{l}\text { Geographical } \\
\text { scope }\end{array}$ & \multicolumn{3}{|c|}{ Urban \& rural areas } & $\begin{array}{l}\text { Urban \& peri- } \\
\text { urban areas }\end{array}$ & $\begin{array}{l}\text { Urban \& rural } \\
\text { areas }\end{array}$ \\
\hline $\begin{array}{l}\text { Population } \\
\text { served }\end{array}$ & $\sim 5,000,000^{*}$ & $\sim 1,100,000$ & 660,000 & $\sim 2,000,000$ & $\sim 500,000$ \\
\hline $\begin{array}{l}\text { No. of } \\
\text { customer } \\
\text { connections }\end{array}$ & $2,400,000 *$ & 270,180 & 290,000 & $\begin{array}{l}182,741 \text { - water } \\
8,727 \text { - } \\
\text { sewerage }\end{array}$ & $\sim 200,000$ \\
\hline $\begin{array}{l}\text { Water sources } \\
\& \text { treatment } \\
\text { processes }\end{array}$ & $\begin{array}{l}\text { Basic } \\
\text { groundwater } \\
\text { treatment + } \\
\text { softening }\end{array}$ & $\begin{array}{l}\text { Surface water } \\
\text { + coagulation, } \\
\text { flocculation, } \\
\text { rapid filtration } \\
\text { \& disinfection }\end{array}$ & $\begin{array}{l}\text { Ground } \\
\text { water \& } \\
\text { surface } \\
\text { water } \\
\text { abstraction + } \\
\text { rapid gravity } \\
\text { filtration, } \\
\text { microfiltrati } \\
\text { on \& } \\
\text { disinfection }\end{array}$ & $\begin{array}{l}\text { Surface water + } \\
\text { pre-chlorination, } \\
\text { coagulation, } \\
\text { flocculation, } \\
\text { clarification, } \\
\text { disinfection \& } \\
\text { neutralisation }\end{array}$ & $\begin{array}{l}\text { surface water + } \\
\text { rapid filtration } \\
+ \text { slow sand } \\
\text { filtration } \\
\text { \&disinfection; } \\
\text { Groundwater + } \\
\text { chlorination - } \\
\text { some sources } \\
\text { with filtration }\end{array}$ \\
\hline
\end{tabular}

*These are aggregate figures for all of the cities served by Utility A

\section{Strategic orientation and corporate planning}

All of the surveyed water utilities had documented mission statements or statements of strategic intent. In addition, four out of the five surveyed utilities had vision statements and core values, as shown in Table 2.

Table 2: Statements of vision, mission and core values for the surveyed water utilities

\begin{tabular}{|c|l|l|l|}
\hline $\begin{array}{c}\text { Surveyed } \\
\text { water utility }\end{array}$ & Vision & $\begin{array}{l}\text { Mission/ Statement of strategic } \\
\text { intent }\end{array}$ & Core values \\
\hline A & $\begin{array}{l}\text { Together we will } \\
\text { provide added value } \\
\text { and meaning to } \\
\text { water. }\end{array}$ & $\begin{array}{l}\text { To provide a top level water } \\
\text { supply to its customers by offering } \\
\text { smart and innovative products and } \\
\text { reliable services, thereby always } \\
\text { striving to improve for the sake of } \\
\text { the environment, the economy, the } \\
\text { society, or the customers }\end{array}$ & $\begin{array}{l}\text { Be trendsetting and } \\
\text { innovative, be } \\
\text { connected, and } \\
\text { continuously identify } \\
\text { new challenges }\end{array}$ \\
\hline B & $\begin{array}{l}\text { Produce and provide cleaned } \\
\text { water in area of the specified city, } \\
\text { and achieve the highest efficiency } \\
\text { with low cost, and satisfy benefits } \\
\text { of the owners and expectation of }\end{array}$ & \\
\hline
\end{tabular}




\begin{tabular}{|c|l|l|l|}
\hline $\begin{array}{c}\text { Surveyed } \\
\text { water utility }\end{array}$ & Vision & $\begin{array}{l}\text { Mission/ Statement of strategic } \\
\text { intent }\end{array}$ & Core values \\
\hline C & $\begin{array}{l}\text { The water supplier of } \\
\text { customer choice }\end{array}$ & $\begin{array}{l}\text { Aim to supply drinking water of } \\
\text { the highest quality providing high } \\
\text { levels of customer service }\end{array}$ & $\begin{array}{l}\text { Excellence } \\
\text { Respect } \\
\text { Integrity }\end{array}$ \\
\hline D & $\begin{array}{l}\text { To be the leading } \\
\text { water utility in the } \\
\text { world. }\end{array}$ & $\begin{array}{l}\text { To provide efficient and cost- } \\
\text { effective water and sewerage } \\
\text { services, applying innovative } \\
\text { management solutions to the } \\
\text { delight of our customers. }\end{array}$ & $\begin{array}{l}\text { Reliability, Integrity, } \\
\text { Honesty, Team Work, } \\
\text { Loyalty, Commitment, } \\
\text { Professionalism and } \\
\text { Innovation }\end{array}$ \\
\hline E & $\begin{array}{l}\text { To be the best water } \\
\text { company in the } \\
\text { country }\end{array}$ & $\begin{array}{l}\text { Supplying clean drinking water to } \\
\text { all household and commercial } \\
\text { properties within our area, we } \\
\text { work hard to put our customers at } \\
\text { the heart of everything we do. }\end{array}$ & $\begin{array}{l}\text { Excellent customer } \\
\text { satisfaction, value for } \\
\text { money compared to } \\
\text { product delivered, } \\
\text { excellent water quality, } \\
\text { delighting the customer } \\
\text { - giving them more } \\
\text { than they ask for }\end{array}$ \\
\hline
\end{tabular}

For sustainable service delivery, a service provider should establish a mission and vision that are well understood, accepted and supported by its staff, and communicate them well to its external publics. For the organisation's strategic objectives to be accepted and supported, all interested parties should be engaged in the strategy and policy formulation. All five surveyed water utilities have a structured process for the formulation and revision of the organisational strategy. Staff members in all five water utilities are involved in the strategic formulation process. Most of the surveyed water utilities also involve the Board of Directors and Government Departments representing the owners of the utilities.

The planning horizon of the strategic plans for the surveyed water utilities varies between 3 to 40 years. The period for reviewing the strategic plans varies between 2-5 years. For all of the surveyed water utilities, the strategies are translated into objectives for various departments of the utilities, and departmental business plans developed to achieve these objectives. The planning cycle of the business plans ranges from 1 to 5 years. In all five water utilities, business plans are used as a framework for budgeting and setting performance targets. For water utilities in the UK, business plans are also used for price setting, asset renewal, and as a tool for communicating with the regulator and the general public.

\section{Organisational Structure}

\section{Departmentalisation}

The most dominant form of departmentalisation in the surveyed water utilities is the functional type. In addition, two utilities, both situated in developing countries, have zonallybased (geographical) business branches within the served cities. The common functions represented in the organisational structures of the surveyed water utilities may be categorised as shown in Table 3. 
Table 3: The functions making up the organisational structures of the surveyed utilities

\begin{tabular}{|c|c|c|}
\hline $\begin{array}{l}\text { Category of } \\
\text { functions }\end{array}$ & $\begin{array}{l}\text { Most common overarching } \\
\text { Departments/Directorates }\end{array}$ & Functions \\
\hline \multirow[t]{2}{*}{$\begin{array}{l}\text { Core business } \\
\text { functions }\end{array}$} & $\begin{array}{l}\text { Operations } \\
\text { Water Supplies } \\
\text { Production/ abstraction \& } \\
\text { purification, plus network } \\
\text { management and delivery } \\
\text { Engineering }\end{array}$ & $\begin{array}{l}\text { Water production } \\
\text { Network operations } \\
\text { Network maintenance/Water loss management } \\
\text { Network planning/Network development } \\
\text { Water quality management } \\
\text { Urban pro-poor branch }\end{array}$ \\
\hline & $\begin{array}{l}\text { Retail /commercial \& } \\
\text { billing/business/customer and } \\
\text { billing }\end{array}$ & $\begin{array}{l}\text { Billing \& IT, Accounts Billing, } \\
\text { Branch/Zone operations } \\
\text { Commercial marketing \& customer care } \\
\text { Field revenue inspection } \\
\text { Debt and credit management } \\
\text { Water supply facilities inspection }\end{array}$ \\
\hline \multirow[t]{2}{*}{$\begin{array}{l}\text { Supporting } \\
\text { functions }\end{array}$} & $\begin{array}{l}\text { Finance \& administration/Finance } \\
\& \text { control }\end{array}$ & $\begin{array}{l}\text { Financial accounting } \\
\text { Management accounting } \\
\text { Cash management } \\
\text { Payroll management } \\
\text { Compliance/internal audit } \\
\text { Stores management and purchasing } \\
\text { Asset management } \\
\text { Human resource management } \\
\text { Human resources development }\end{array}$ \\
\hline & Corporate services & $\begin{array}{l}\text { Legal services/Company secretary } \\
\text { Corporate planning } \\
\text { Information technology management } \\
\text { Liaison with economic regulators } \\
\text { Security services } \\
\text { Estates management } \\
\text { Transport management } \\
\text { Investment and capital development } \\
\text { Performance monitoring and evaluation } \\
\text { Communication/public relations management }\end{array}$ \\
\hline
\end{tabular}

As can be seen from Table 3, supporting functions are clustered in various ways, as follows:

- The human resources management function could stand alone or form part of the Corporate Services Directorate.

- Similarly, non-financial support functions such as compliance/internal audit, legal services, communications and public relations, etc. may form standalone departments, or could be part of the Finance and Administration Directorate or Corporate Services Directorate. 
- Asset management, estates management, capital development, transport management could be clustered under the Engineering Directorate, depending on the extent to which the office holders are technically orientated.

All of the surveyed water utilities reportedly often form cross-functional teams to solve specific problems. Task forces have in the past been formed in Utility D to increase revenue collection, reduce non-revenue water, reduce illegal connections, and reduce suppressed accounts. Utility E has formed a task force to evaluate the company's carbon footprint and identify remedial actions. The formation of the task forces points to the flexibility exhibited by the water utilities to adopt matrix organisation structures as and when it is deemed necessary.

\section{Work specialisation}

There is a significant level of specialisation in the surveyed water utilities. For instance, all of the surveyed water utilities have specialised functions of finance and accounting, human resources management, legal services, water loss management, water quality control, information management, planning and development, customer relations management, and communications/public relations. It is also worth noting that chief executive officers for two of the surveyed water utilities are professionals in business management and finance.

Apart from the utility located in South East Asia, all of the surveyed water utilities outsource some specialised tasks from external organisations, amounting to 10 to $40 \%$ of the operating costs. Examples of outsourced specialised tasks include laboratory services, network repairs/maintenance and debt collection. Branch Managers in two of the utilities, who would most likely be engineers by profession, report to a top manager in charge of commercial/business services.

\section{Chain of command}

All of the surveyed water utilities depict a line-and-staff organisational setup, which combines the line organisation with staff departments that support and advise line departments. The line functions are the core business functions, while the staff functions are the non-core, support staff, as shown in Table 3 (above). The organisational chart for one water utility explicitly differentiates between core departments, directing staff departments and support departments. In such a line-and-staff organisation, staff personnel use their technical expertise to support line staff and advise top management in the various business activities.

To further analyse the chain of command for the various utilities, the ratios of staff to the management teams were calculated, as shown in Figure 2. Utility $\mathrm{C}$ has a flatter organisational structure, with no middle management layer. The larger ratios of top to middle managers in utilities $\mathrm{D}$ and $\mathrm{E}$ indicate opportunities for decentralisation of authority if the top managers are willing to delegate the authority to lower levels. 


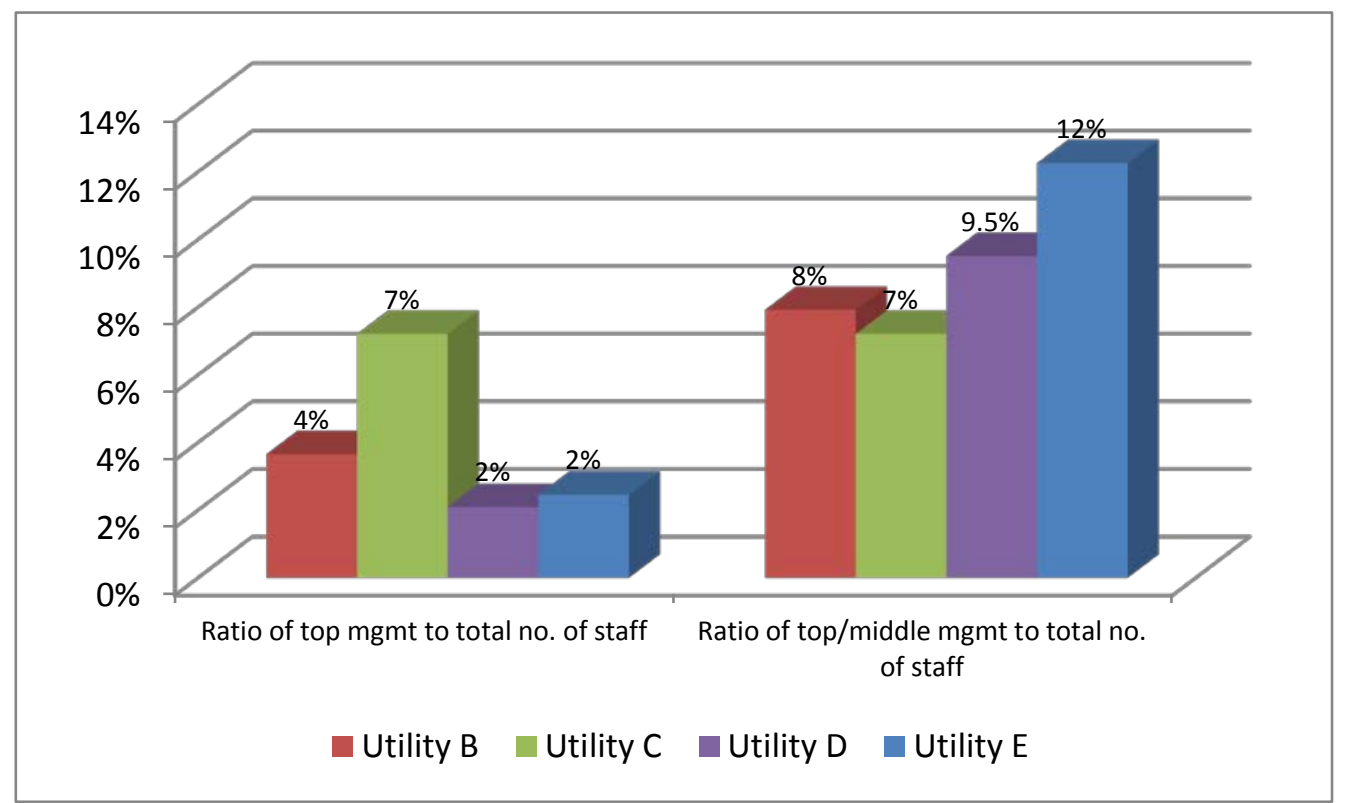

Figure 2: Various ratios related to composition of the workforce

\section{Span of control}

Three of the surveyed water utilities provided enough information to enable calculation of the average span of control for heads of department. As seen in Figure 3, the spans of control in Utilities C and E are much lower than those in Utilities B and D. A key factor is the level of automation in tasks for the water production, operation and maintenance of the water supply system, meter reading, and bill delivery; automation is much higher in industrialised countries (i.e., UK) than in the low-income countries (South East Asia and Sub-Saharan Africa). The level of automation directly affects the type of work assigned to staff involved in these departments, most of which are standardised routine procedures. Another important factor is the geographical departmentalisation to zones within cities, as implemented by Utilities B and D.

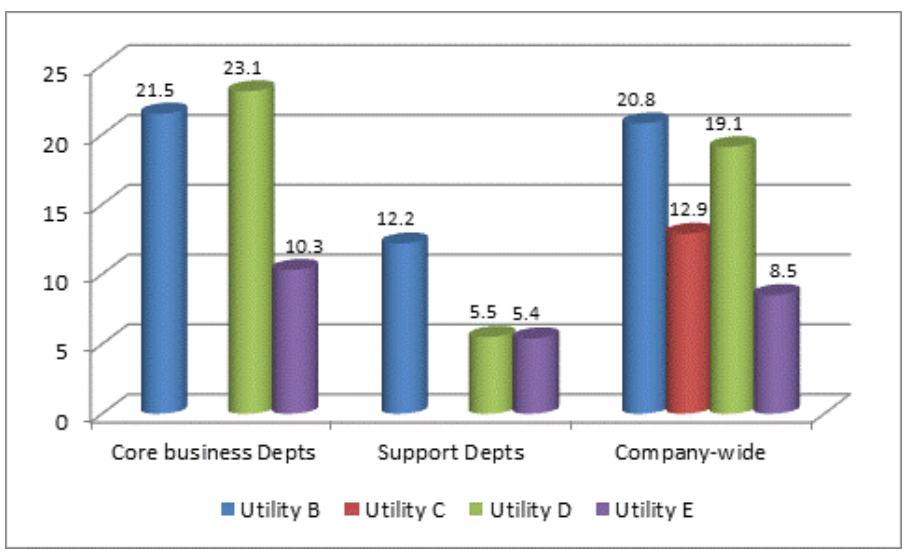

Figure 3: Average spans of control in the surveyed water ${ }^{\ddagger}$

\footnotetext{
${ }^{\ddagger}$ Breakdown of staff according department not available for Utility C
} 
The results shown in Figure 3 also highlight the degree of specialisation as an important factor in deciding the span of control. For the three water utilities that provided data, the span of control for support services is much lower than that for the core business departments. Support functions such as legal services, human resource management, accounting and internal audit usually require higher skills and more specialisation, compared to lower-level, repetitive tasks in the core business departments, such as pump operation and pipe-laying. This should be a consideration in the design of the organisation structure for the proposed city-owned water utilities.

\section{Formalisation}

All of the surveyed utilities have established job descriptions for their staff. The questionnaire sent to the water utilities also asked if there are documented policies and procedures for governing human resources management/development and financial/asset management; and standard operating procedures for technical and commercial process management in the organisation. The water utilities mostly answered in the affirmative for the tasks considered, as described in greater details in the next sections.

\section{Management of processes}

Four out of five water utilities surveyed (two in developing countries and two in developed countries) indicated that their organisations are accredited by ISO quality management systems (i.e., conforming to ISO 9000/1 quality management standards). A quality management system (QMS) refers to what an organization does to fulfil customer's quality requirements, and relevant regulatory requirements, while aiming to enhance customer satisfaction and achieve continual improvement of its performance. A QMS is composed of the management structure, responsibilities, procedures, mechanisms, processes, and management resources to implement the principles and action lines needed to achieve the quality objectives of an organisation (CERCO Working Group on Quality, 2000). The main thrust of a QMS is defining the processes, in a systematic and transparent manner to ensure achievement of quality and customer satisfaction. The proceeding paragraphs briefly describe the key documented management processes in the surveyed water utilities.

\section{Technical process management}

Technical attributes of a water utility's service bundle are crucial in inducing customer satisfaction, and play a vital role in their evaluations of service value, which in turn leads to higher willingness-to-pay for the water services (Kayaga et al., 2003; Kayaga et al., 2004). For better results, a water utility should manage technical processes, to ensure that they are effective and efficient, and adopt a systems approach to management, by creating and understanding the network of processes, their sequences and interactions. Effective quality management systems require that records and documents are established and maintained to provide evidence of conformity and effective operation (Kayaga et al., 2014). All of the surveyed water utilities indicated that they had defined operating standards for managing the technical processes. Table 4 summarises of the results of the survey. 
Table 4: Key documented procedures for the various technical processes

\begin{tabular}{|c|c|c|}
\hline Process & Existing documentation & Remarks \\
\hline $\begin{array}{l}\text { Managing the quality } \\
\text { of raw water }\end{array}$ & $\begin{array}{l}\text { Policy and procedures for water } \\
\text { resources management in the } \\
\text { catchment area }\end{array}$ & $\begin{array}{l}\text { Exist in all of the utilities except } \\
\text { Utility D. The utilities in the UK } \\
\text { work in collaboration with UK's } \\
\text { Environmental Agency }\end{array}$ \\
\hline Water treatment & $\begin{array}{l}\text { Standard operation procedures for } \\
\text { water treatment process }\end{array}$ & \multirow{8}{*}{ Exist in all of the surveyed utilities } \\
\hline Energy efficiency & $\begin{array}{l}\text { Processes and procedures for energy } \\
\text { efficiency management }\end{array}$ & \\
\hline \multirow[t]{2}{*}{$\begin{array}{l}\text { Water quality } \\
\text { management }\end{array}$} & $\begin{array}{l}\text { Water quality management policies } \\
\text { and procedures for whole water } \\
\text { supply chain }\end{array}$ & \\
\hline & $\begin{array}{l}\text { Water Safety Plans (WSPs) \& their } \\
\text { use }\end{array}$ & \\
\hline $\begin{array}{l}\text { Maintenance of } \\
\text { electro-mechanical } \\
\text { plant/equip. }\end{array}$ & $\begin{array}{l}\text { Planned preventive maintenance } \\
\text { systems and procedures }\end{array}$ & \\
\hline \multirow[t]{3}{*}{ Water distribution } & $\begin{array}{l}\text { Standard operating procedures for } \\
\text { water distribution networks }\end{array}$ & \\
\hline & $\begin{array}{l}\text { Planned preventive maintenance } \\
\text { policy, procedures and systems }\end{array}$ & \\
\hline & $\begin{array}{l}\text { Water leakage management policy, } \\
\text { procedures and systems }\end{array}$ & \\
\hline $\begin{array}{l}\text { Customers' meter } \\
\text { management }\end{array}$ & $\begin{array}{l}\text { Water meter maintenance policy, } \\
\text { procedures and systems }\end{array}$ & $\begin{array}{l}\text { Exist in all of the surveyed } \\
\text { utilities. }\end{array}$ \\
\hline \multirow[t]{2}{*}{ Overall } & Risk management systems & Exist in Utilities A, B, C, and E \\
\hline & Technology adoption plans & Exist in Utilities A, C, D, and E \\
\hline
\end{tabular}

With very minor exceptions, all of the surveyed utilities indicated they had established management and operational systems for implementing the technical processes, as evidenced by the existence of documented procedures that support the systems. These findings are consistent with the utilities' indication that they are accredited under ISO 9000 series of quality management systems.

\section{Commercial process management}

Table 5 reports the existence of documented policies, procedures manuals and systems for managing various commercial processes. The listed procedures are standard in all of the surveyed water utilities, except for decentralisation of customer service centres to smaller, viable zones, which is not done in Utility E. Geographical decentralisation is more desirable in business environments in the developing countries, where customers may need to physically travel to the service centre to have their complaints resolved. However, Utility E has an agreement with a private consulting firm to handle excessive calls during the peak periods. 
Table 5: Key documented procedures for the various commercial processes

\begin{tabular}{|c|c|c|}
\hline Process & Existing documentation & Remarks \\
\hline $\begin{array}{l}\text { Acquiring new } \\
\text { customers }\end{array}$ & $\begin{array}{l}\text { Policy and procedures manual for } \\
\text { new connections }\end{array}$ & \multirow{8}{*}{ Exist in all of the surveyed utilities } \\
\hline \multirow{2}{*}{$\begin{array}{l}\text { Metering and } \\
\text { meter } \\
\text { management }\end{array}$} & $\begin{array}{l}\text { Policy and procedures manual for } \\
\text { fitting meters on customer premises }\end{array}$ & \\
\hline & $\begin{array}{l}\text { Policy and procedures manual for } \\
\text { managing customer meters }\end{array}$ & \\
\hline Meter reading & $\begin{array}{l}\text { Policy and procedures manual for } \\
\text { meter reading }\end{array}$ & \\
\hline $\begin{array}{l}\text { Reduction of } \\
\text { water losses }\end{array}$ & $\begin{array}{l}\text { Policy and procedures manual for } \\
\text { reduction of non-revenue water }\end{array}$ & \\
\hline \multirow[t]{3}{*}{$\begin{array}{l}\text { Revenue } \\
\text { collection }\end{array}$} & $\begin{array}{l}\text { Annual billing and revenue collection } \\
\text { business plan }\end{array}$ & \\
\hline & $\begin{array}{l}\text { Policy and procedures manual for } \\
\text { revenue collection }\end{array}$ & \\
\hline & $\begin{array}{l}\text { Policy and procedures manual for } \\
\text { debt collection }\end{array}$ & \\
\hline \multirow{5}{*}{$\begin{array}{l}\text { Customer } \\
\text { service and } \\
\text { customer care }\end{array}$} & $\begin{array}{l}\text { Customer service structures - } \\
\text { customer call centres/ help desks }\end{array}$ & Exist in all of the surveyed utilities. \\
\hline & $\begin{array}{l}\text { Customer complaints management } \\
\text { systems }\end{array}$ & \multirow[t]{2}{*}{ Exist in all of the surveyed utilities. } \\
\hline & $\begin{array}{l}\text { Customer charter specifying } \\
\text { customer service standards and codes } \\
\text { of practice }\end{array}$ & \\
\hline & Regular customer satisfaction surveys & $\begin{array}{l}\text { Exist in all of the surveyed utilities: } \\
\text { monthly for Utility A; quarterly for } \\
\text { Utilities D \& E; and annually for Utilities B } \\
\text { \& C }\end{array}$ \\
\hline & $\begin{array}{l}\text { Decentralisation of customer services } \\
\text { into viable zones }\end{array}$ & Exist in Utilities A, B, C, and D \\
\hline
\end{tabular}

\section{Financial and asset management processes}

Financial management systems are usually driven by legal requirements. They also enable an organisation to control its available resources, through documenting a clear division of responsibilities and specific controls. Table 6 reports documented procedures for financial and asset management implemented by the surveyed water utilities. Asset management and planning is integrated with financial management in all of the surveyed water utilities, except for the case of Utility A where maintenance and stores management systems are not fully integrated. 
Table 6: Key documented procedures for the financial and asset management

\begin{tabular}{|l|l|l|}
\hline Aspect & Existing documentation & \multirow{2}{*}{ Remarks } \\
\hline $\begin{array}{l}\text { Financial } \\
\text { management }\end{array}$ & $\begin{array}{l}\text { Policy and procedures manual for } \\
\text { financial operations }\end{array}$ & \multirow{2}{*}{$\begin{array}{l}\text { Exist in all of the surveyed } \\
\text { utilities }\end{array}$} \\
\hline Internal audit & $\begin{array}{l}\text { Internal audit policy and procedures } \\
\text { manual }\end{array}$ & \\
\cline { 1 - 2 } Asset management & Asset registry & \multirow{2}{*}{ Exist in Utilities B, C, D, and E } \\
\cline { 2 - 2 } Stores management & $\begin{array}{l}\text { Asset replacement/management plans } \\
\text { financial management systems }\end{array}$ \\
\cline { 2 - 2 } & $\begin{array}{l}\text { Stores management integrated with } \\
\text { maintenance management systems }\end{array}$ \\
\hline
\end{tabular}

\section{Human Resource Management and Development}

Human resource capacity in any organisation is key and critical to the implementation of the organisational processes and delivery of services to its customers. An effective water utility should have human resource management (HRM) and development systems that translate the organisation's strategic and process objectives into the individual job objectives of staff members, establish plans for their realisation, and implement actions to continuously acquire and improve the required competences as the need arises. Table 7 reports HRM policies, procedures, and systems implemented by the surveyed water utilities.

Table 7: Key documented procedures for the HRM and development

\begin{tabular}{|c|c|c|}
\hline Aspect & Existing documentation & Remarks \\
\hline \multirow{4}{*}{$\begin{array}{l}\text { Human resource } \\
\text { management }\end{array}$} & HRM policy and procedures manual & \multirow{5}{*}{ Exist in all of the surveyed utilities } \\
\hline & Clear job descriptions for all staff & \\
\hline & $\begin{array}{l}\text { Regular staff performance appraisals } \\
\text { and promotion framework }\end{array}$ & \\
\hline & $\begin{array}{l}\text { Occupational health and safety } \\
\text { policy and procedures manual }\end{array}$ & \\
\hline \multirow[t]{2}{*}{$\begin{array}{l}\text { Human resource } \\
\text { development }\end{array}$} & $\begin{array}{l}\text { Annual training and capacity } \\
\text { development plans }\end{array}$ & \\
\hline & $\begin{array}{l}\text { Regular human capacity } \\
\text { development needs assessment }\end{array}$ & Exist in Utilities C, D, and E \\
\hline
\end{tabular}

\section{Information Technology}

Information Technology (IT) is a critical success factor in the modern world, affecting how organisations produce and deliver their goods/services, as well as how staff communicate and accomplish their jobs in the organizations. An effective water utility should establish, implement, and maintain processes for managing technology, information, and knowledge as essential resources. Table 8 reports how IT processes have been deployed in various functions of the surveyed water utilities. 
Table 8: Key decision support tools

\begin{tabular}{|l|l|l|}
\hline Aspect & Existing & Remarks \\
\hline \multirow{5}{*}{ Technical processes } & Network hydraulic simulation & Exist in Utilities B, C, D, and E \\
\cline { 2 - 2 } & $\begin{array}{l}\text { Geographical Information Systems and } \\
\text { Infrastructure Global Positioning System }\end{array}$ & $\begin{array}{l}\text { Exist in all of the surveyed } \\
\text { utilities }\end{array}$ \\
\cline { 2 - 2 } & $\begin{array}{l}\text { Supervisory Control and Data Acquisition } \\
\text { (SCADA) systems }\end{array}$ & \\
\hline Business management & $\begin{array}{l}\text { IT-based billing and revenue collection } \\
\text { system, integrated with customer services } \\
\text { management }\end{array}$ & \\
\hline $\begin{array}{l}\text { Financial and asset } \\
\text { management }\end{array}$ & Integrated accounting system & \multirow{2}{*}{ Exist in Utilities A, B, C, and E } \\
\cline { 2 - 2 } & $\begin{array}{l}\text { Integrated asset management and planning } \\
\text { system }\end{array}$ & $\begin{array}{l}\text { Personnel Information Management } \\
\text { System }\end{array}$ \\
\hline $\begin{array}{l}\text { Human Resource } \\
\text { Management }\end{array}$ & \multicolumn{2}{|c|}{} \\
\hline
\end{tabular}

\section{Performance Management}

The existence of internal accountability mechanisms and systems has been found to be a key ingredient for improving organisational performance. Indicators of internal accountability include whether performance targets for individual staff members are well defined and provide incentives, sanctions or both (Baietti et al., 2006). Another driver for organisational performance is whether the utilities are held accountable for performance standards. Table 9 reports aspects of performance management that are implemented by the surveyed water utilities.

There are several similarities and differences in the way the surveyed utilities manage the performance of their staff for enhanced internal accountability. All of the surveyed utilities evaluate individual performance on an annual basis. However, Utility C did not have a mechanism for paying performance-based incentives for its staff. Utility E pays incentives through annual performance-based salary increments, while Utility D pays incentives monthly. Utility B processes payments for incentives annually and in on ad-hoc basis, depending on incidences of good performance. Utility A also makes ad-hoc performancebased payments.

Apart from Utility E, all of the surveyed water utilities evaluate the performance of teams of staff, in addition to individual evaluation. However, only Utilities B and D, both located in developing countries, pay performance-based incentives to the teams. Utility B makes payments to teams annually or incidentally, while Utility D makes the payments monthly and quarterly. 
Table 9: Performance management mechanisms existing in the surveyed water utilities

\begin{tabular}{|l|l|l|}
\hline Aspect & Existing mechanisms & Remarks \\
\hline $\begin{array}{l}\text { Internal } \\
\text { accountability }\end{array}$ & $\begin{array}{l}\text { Annual appraisal of performance of } \\
\text { individual staff }\end{array}$ & Exist in all of the surveyed utilities \\
\cline { 2 - 3 } & $\begin{array}{l}\text { Regular appraisal of overall } \\
\text { performance of teams of staff }\end{array}$ & $\begin{array}{l}\text { Exist in all of the surveyed utilities; } \\
\text { done quarterly in Utility D and } \\
\text { annually in the rest of the utilities }\end{array}$ \\
\cline { 2 - 3 } & $\begin{array}{l}\text { Mechanism for paying performance- } \\
\text { based incentives to individual staff }\end{array}$ & $\begin{array}{l}\text { Exist in all of the surveyed utilities } \\
\text { except in Utility C }\end{array}$ \\
\cline { 2 - 3 } & $\begin{array}{l}\text { Mechanism for paying performance- } \\
\text { based incentives for teams of staff }\end{array}$ & Exist in only two utilities - B and D. \\
\cline { 2 - 3 } & $\begin{array}{l}\text { Staff performance monitoring } \\
\text { focused on customer satisfaction }\end{array}$ & Exist in all of the surveyed utilities \\
\cline { 2 - 3 } & $\begin{array}{l}\text { Corporate continuous performance } \\
\text { improvement plans, with key } \\
\text { performance indicators in key results } \\
\text { areas such as revenue collection, } \\
\text { reduction of NRW, customer } \\
\text { satisfaction and cost optimisation }\end{array}$ & Exist in all of the surveyed utilities \\
\hline $\begin{array}{l}\text { Eerformance agreement/contract with } \\
\text { its owners }\end{array}$ & $\begin{array}{l}\text { Exsemination of the company’s key } \\
\text { performance indicators to the public. }\end{array}$ & Exist in Utilities A, B, C, and E A, B, and D \\
\hline
\end{tabular}

\section{Discussion and Conclusion}

Various studies carried out by the World Bank and other international development agencies show that among the main factors to contributing to poor performance by urban water service providers in developing countries are the inappropriate organisational structures and management systems put in place for service delivery. In this paper, we conceptualise effective OD to address these deficiencies as the practice of consciously aligning an organisation's structure, processes, management systems, and culture with a well-articulated strategy. Organisational design not only provides greater ability to carefully allocate resources to drive the strategy but also enables the development of a high-performance culture (McGee and Molloy, 2003). To explore these concepts, we examined key aspects of organisational design for five water utilities from South East Asia, Europe, and Africa, each of which are considered well-performing service providers by the World Bank's International Benchmarking Network for Water and Sanitation Utilities (IBNET).

The focus of OD is mainly the internal business processes, while the performance of water utilities is largely affected by the institutional and policy environment in which they operate (Kayaga et al., 2013), especially so if they are government-owned. Many performance improvement initiatives in the past have focused on carrying out $\mathrm{OD}$, without adequately addressing the institutional and policy environment, and more importantly, the decision makers that influence incentives both within and outside the organisation - leading to disappointing results (Baietti et al., 2006). It is imperative to adapt the design in accordance with existing institutional frameworks at the federal and regional levels of government.

All of the surveyed water utilities have vision statements, expressing where they want to be. The utilities also have mission statements or statements of strategic intent. Staff members of 
all of the surveyed water utilities are involved in the strategic formulation process, and the government owners of the utility are also consulted. The business plans for all of the surveyed water utilities evolve from the strategic plans. Strategic planning is an important process that enables the leadership of an organisation to rally its human resources around the statements of strategic intent, to work towards achieving sustainable success. These statements also communicate to the outside world what the organisation wants to be and how it wants to be seen by stakeholders. As is the case with the surveyed water utilities, strategic plans should be periodically reviewed, after a process of scanning the operating environment to identify potential opportunities and threats. It may be difficult for a water utility to sustain or even establish a strategic direction in disenabling institutional environment, as happens with a restrictive legal framework or political interference (Baietti et al., 2006).

The organisational structures of all of the water utilities that participated in the study are predominantly based on a functional type of departmentalisation, with four of the five utilities having some flexibility in forming cross-functional work teams to tackle some specific challenges as necessary. The departments or directorates are commonly structured between two groups of functions: (i) core functions composed of operations or water supply or production/network management/engineering, business or retail or commercial or billing/customer services); and (ii) support functions, composed of finance and administration or finance and control, and corporate services. All of the surveyed water utilities depicted a line-and-staff chain of command, where staff personnel (in the support departments) use their technical specialities to support line staff (in the core departments) and advise top management. However, the dual authority system, which approximates a matrix structure, must be well managed to harness the advantages such as enhanced efficiency, flexibility and improvement of motivation/commitment, while minimising conflicts that arise from the dual reporting system. Key factors for determining the organisational structure and chain of command are (i) the geographical spread of the service delivery; (ii) the service portfolio (e.g. whether water services only or water and sewerage services); and (iii) the corporate culture, which to a large extent is influenced by leadership and the prevailing national political situation.

Functional departmentalisation is consistent with and supported by the elevated levels of work specialisation that is exhibited by most tasks undertaken in the provision of water services. It is worthwhile noting that high levels of formalisation of jobs make it easier for organisations to design higher spans of control. The high level of formalisation of the jobs in the water utilities is enhanced by: (i) specialized technical and business processes that are amenable to the development of documented work rules and procedures; and (ii) functional departments that are made up of jobs with similarities with written instructions for guiding the staff.

As part of the formalisation process, all of the surveyed water utilities are accredited by ISO 9000 series of standards, which certify that the utilities use quality management systems (QMS) as a framework for establishing the utility's objectives and managing resources for their achievement. Adoption of QMS requires that all processes in an organisation are systematically defined and managed to fulfil the customer's quality requirements and applicable regulatory requirements, ensure customer satisfaction, and achieve continuous improvement of the organisation's performance (ISO, 2008). The surveyed water utilities have documented policies and Standard Operating Procedures (SOPs) for all major technical and business-management processes.

Additionally, the surveyed water utilities implement integrated accounting systems and have in place policies, procedures and manuals for financial management, internal audit, asset 
management and stores management. These systems enable the utilities to effectively monitor and control efficient allocation and use of organisational resources. The human resource management processes are well-defined, measured and reviewed, and integrated within the day-to-day operations, which enhances staff motivation. Furthermore, the surveyed utilities have a process in place to identify, obtain, protect, use and evaluate information, knowledge and technology concerning the organisational products and processes. The utilities regularly appraise the performance of the employees and teams in terms of customer satisfaction indices. All but one also established mechanisms and procedures for paying performancebased incentives to individual employees. Performance management is a recognised tool for organisational accountability.

These characteristics are typical of organisations that are implementing QMS. Increasingly, effective and well-performing water utilities worldwide have adopted this approach to business management. Organisational redesign that adopts QMS is expected to: (i) lead to lower costs through shorter cycle times and more effective use of resources; (ii) lead to improved, consistent and predictable performance results; and (iii) trigger a sharper focus on prioritised improvement opportunities (ISO, 2008). However, full-scale ISO 9001 certification has been found to be manufacturing-centric and is not necessarily proven to lead to improvements in the organisational performance of water utilities (Kayaga et al., 2014). Further empirical research is needed on the link between performance improvements and QMS-led OD in the water sector.

The extant literature suggests a significant link between OD and performance of private firms, which is strongly moderated by the operating environment. We found many similarities in the OD of the five water utilities studied, all of which were considered 'high-performing' by the World Bank's International Benchmarking Network for Water and Sanitation Utilities (IBNET) 2010 database. However, the OD-performance link may not be as strong for public water utilities as for private companies, as moderating factors in the operating environment are expected to be more relevant given greater influence from various governmental institutions that typically own, fund, and regulate urban water utilities. Nonetheless, OD can be adapted to a water utility's institutional context.

\section{Acknowledgements}

This study was sponsored by the Water Global Practice of the World Bank. We are grateful to key informants in the five anonymous water utilities serving in the various cities of the world who participated in the study.

\section{References}

1. Andrews, M., Pritchett, L. and Woolcock, M. 2012. Escaping capability traps through problem-driven iterative adaptation (PDIA). Centre for Global Development, Working Paper 299, Harvard University, Cambridge, MA, USA.

2. Baietti, A., Kingdom, W. and van Ginneken, M. 2006. Characteristics of wellperforming public water utilities. Water Supply and Sanitation Working Note No. 9, The World Bank, Washington DC.

3. Baser, H., Morgan, P., Morgan, J., Brinkerhoff, D., Land, A., Taschereau, S. Watson, D. and Zinke, J. 2008. Capacity, Change and Performance, Discussion Paper No. 59B, European Centre for Development Policy Management. 
4. Berg, S. V. 2010. Water Utility Benchmarking: Measurement, Methodologies, and Performance Incentives, IWA Publishing, London, UK.

5. Bhattacharya, A. and Kundu, A. 2013. Organisation design and performance: evidence from India, International Journal of Management and Marketing Research, 6(2), 93-107.

6. BusinesDisctionary.com, 2015. Definition of Authority, available at http://www.businessdictionary.com/definition/authority.html, accessed on 9 December 2015.

7. CERCO Working Group on Quality (2000) Handbook for Implementing a Quality Management System in a National Mapping Agency, available at $\quad$ http://www.eurogeographics.org/sites/default/files/handbook_V1.pdf, accessed on 1 Jan 2016.

8. Connor, G., McFadden, M. and McLean, I. 2012. Organisational Design, in: Stewart, J. and Rogers, P. (eds), Developing People and Organisations. Chartered Institute of Personnel and Development (CIPD), London.

9. Daft R.L. and Lewin, A.Y. 1993. Where are the theories for the 'new' organizational forms? An editorial essay. Organization Science, 4(4), i-vi.

10. Daft, R. 2007. Understanding the theory and design of organisations. Thomson South Western, Mason, $\mathrm{OH}$.

11. Huczynski, A. and Buchanan, D. 2007. Organisational Behaviour, sixth ed. Prentice Hall, Harlow.

12. ISO (2008) Managing for the sustained success of an organisation - a quality management approach, ISO.

13. Kaplan, R.S. 2010. Conceptual Foundations of the Balanced Scorecard, Working Paper 10-047, Harvard Business School, Harvard University.

14. Kaplan, R.S. 2005. How the balanced scorecard complements the McKinsey 7-S model", Strategy and Leadership, 33(3), 41 - 46.

15. Kaplan, R.S. and Norton, D.P. 2001a. Transforming the balanced scorecard from performance measurement to strategic management: Part I. Accounting Horizons 15(1): 87-104.

16. Kaplan, R.S. and Norton, D.P. 2001b. Transforming the balanced scorecard from performance measurement to strategic management: Part 2. Accounting Horizons, 15(2), 147-160.

17. Katz, D.K. 1966. The Social Psychology of Organisations. Wiley, New York.

18. Kayaga S., Franceys, R. and Sansom, K. 2004. Bill Payment Behaviour in Urban Water Services: Empirical Data from Uganda, Journal of Water Supply: Research and Technology- Aqua, 53 (5) pp. 339-349, IWA Publishing, UK

19. Kayaga, S., Calvert, J. and Sansom, K. 2003. Paying for water: Effects of Household Characteristics; Utilities Policy, 11 (3) pp.123-132, Elsevier Science, USA

20. Kayaga, S., Mugabi, J. and Kingdom, W. 2013. "Evaluating the institutional sustainability of an urban water utility: a conceptual framework and research directions”, Utilities Policy, 27, pp.15-27.

21. Kayaga, S., Mugabi. J and Kingdom, W. 2014. Can ISO 9001 certification of water utilities in developing countries be used to evaluate institutional sustainability? OIDA International Journal of Sustainable Development 7(9), 35-70. 
22. McGee, E.C. and Molloy, K. 2003. Getting results through Organization Design, available at http://www.grovewell.com/wp-content/uploads/pub-org-design.pdf, accessed on 7 November 2015.

23. McNamara, C. 2015. Basic definition of organisation, Online integrated library for personal, professional and organisational development, available at http://managementhelp.org/organizations/definition.htm , accessed on 18 October 2015.

24. Misra, S., Kingdom, W. 2012. India - Improving Urban WSS Service Provision. Lessons from Business Plans for Maharashtra, Rajasthan and Haryana and International Good Practices. World Bank and Ministry of Urban Development, Government of India.

25. North, D.C. 1990. Institutions, Institutional change and economic performance. Cambridge University Press, New York.

26. Roberts, J. (2007) The Modern Firm: Organizational Design for Performance and Growth, Oxford University Press, ISBN 978-0-19-829375-0 (paperback edition).

27. Sepehri, P., Mousavi, S., Khajehnejad, S., Madani, F. and Moeindarbari, G. 2011. Designing a proper organisational chart for a project-oriented company through studying its conceptual and structural dimensions. $3^{\text {rd }}$ International Conference on Information and Financial Engineering, IPEDR, 12, 222-227. IACTSIT Press, Singapore.

28. Simons, R. 2005. Leverages of organization design, Harvard Business School Press, Boston.

29. UNDP 2008. Capacity Development, Practice Note, New York.

30. UNICEF and World Health Organization (WHO) 2015. Progress on Sanitation and Drinking Water - 2015 update and MDG assessment, Geneva, Switzerland.

31. UNICEF and WHO 2017. Safely managed drinking water - thematic report on drinking water 2017, New York, USA.

32. Van de Ven, A.H. 1976. A framework for organisational assessment, Academy of

33. World Bank (The), 2014. The IBNET Water Supply and Sanitation Blue Book 2014: The International Benchmarking Network for Water and Sanitation Utilities Databook, Washington DC. 